\title{
Forced Aeration Influence on the Production of Spores by Trichoderma strains
}

\author{
Reynaldo De la Cruz-Quiroz ${ }^{1} \cdot$ Felipe Robledo-Padilla ${ }^{2}$ Cristóbal N. Aguilar ${ }^{1} \cdot$ \\ Sevastianos Roussos ${ }^{3}$
}

\begin{abstract}
The main purpose of the present study was to evaluate the effect of an initial aeration rate on the sporulation of six Trichoderma strains under solid state fermentation conditions and to evaluate the behavior of the lytic enzymes involved in the process at laboratory scale. A mixture of sugarcane bagasse, wheat bran, chitin, potato flour and olive oil were used as a substrate. Cultures were carried out using glass columns applying an initial aeration rate of

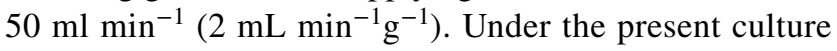
conditions, chitinase and amylase activities were enhanced by the aeration with values of 30.74 and $44.54 \mathrm{U} \mathrm{g}^{-1}$ with T. longibranchiatum. These vales represent an increase of 226 and $167 \%$, respectively compared with the system without air supply. For most of the strains, the forced aeration increased the endoglucanase activity, but the best value was observed with $T$. yunnanense $\left(38.32 \mathrm{U} \mathrm{g}^{-1}\right)$. All strains showed low values of exoglucanase and lipase when the aeration was applied. Trichoderma spp. was the strain most affected negatively by the aerated process, showing the lowest enzyme activities. The forced air supply into solid-state
\end{abstract}

Reynaldo De la Cruz-Quiroz reynaldocq87@hotmail.com

Sevastianos Roussos

sevastianos.roussos@imbe.fr

Department of Food Research, School of Chemistry, Universidad Autónoma de Coahuila (UAdeC), V. Carranza s/n, 25280 Saltillo, Mexico

Tecnológico de Monterrey, Escuela de Ingeniería y Ciencias, Ave. Eugenio Garza Sada 2501, 64849 Monterrey, Nuevo León, Mexico

Institut Méditerranéen de Biodiversité et d'Ecologie marine et continentale (IMBE), Aix-Marseille Université, UMR CNRS/IRD/Univ. Avignon-FST St-Jérôme, case 421, 13397 Marseille cedex 20, France fermentation did not improve the production of spores from Trichoderma since similar results were obtained in the process without forced aeration. On this report, we reach concentrations greater than $1 \times 10^{9}$ spores per gram of substrate at $96-120 \mathrm{~h}$ of culture, indicating a feasible approach of agro-industrial wastes as a substrate for the biomass production.

Keywords Solid-state fermentation - Agro-industrial wastes $\cdot$ Cellulases $\cdot$ Chitinase $\cdot$ Amylase $\cdot$ Lipase

\section{Introduction}

Trichoderma is considered as one of the most popular biological control agent (BCA) against several plant pests due to the diversity of its mechanisms of action, including the competence for nutrients and space, antibiotics production, and mycoparasitism mediated by the production of lytic enzymes [1,2]. Trichoderma strains are a potential alternative to chemical pesticides applied in the food crops due to the harmful impact on the ecology and human health caused by the wrong and excessive application of pesticides, the waste generation, the destruction of non-target organisms, and induction of pests resistant to pesticides [3, 4].

The main challenge faced by BCA products is its low availability and distribution due to the limited production of fungal biomass [5]. The fungal spore is the most resistant propagule that tolerates the critical environmental conditions presented in the field crops [6, 7]. Therefore, the production of spores from BCA's is a core point to gain ground to the chemical pesticides. Several reports have been published on the topic of spore production from different BCA's, such as Loera-Corral et al. [6] evaluating Metarhizium anisopliae, Lopez-Perez et al. [8] with Beauveria bassiana or de la 
Cruz-Quiroz et al. [9] with Trichoderma asperellum, among others.

Solid-state fermentation (SSF) is a microbial process with the high potential to produce fungal biomass, and also other several kinds of value-added products such as antibiotics, pigments, aromas, and enzymes of industrial interest like cellulases, chitinases, amylases, etc., [10-13]. The SSF allows the valorization of agro-industrial wastes generating a positive impact on the worldwide ecology due to this material could be used as the carbon source to the fungal development showing excellent yields for the production of fungal spores [14-16]. Sugarcane bagasse (SCB) is the major agroindustrial waste generated globally. SCB is an inexpensive material rich in cellulose $(50 \%)$, hemicellulose $(25 \%)$ and lignin $(25 \%)$ which can be used for the generation of value added products, such as enzymes or biomass [17, 18]. Due to its low concentration of ashes, it is an excellent substrate for bioconversion process offering great approaches instead of wheat bran or rice bran, among others [19]. SSF is an aerobic process, therefore is highly needed an adequate oxygen diffusion through the fermented matter making one of the most important phenomena to support the microbial development [20]. Commonly a passive oxygen diffusion takes place in reactors such as flasks, trays or bags resulting in a high production of spores [14, 16, 21]. Arzumanov et al. [22] reported that the aeration does not always make a big difference to increase the production of spores. Nevertheless, several authors suggest that forced aeration is a key point to increase or optimize the spore production from different filamentous fungi $[20,23]$. Therefore, the oxygen diffusion inside of the system, the removal of heat and $\mathrm{CO}_{2}$ from the fermented matter caused by the forced aeration could be a possible alternative to increase the spore production using the Raimbault columns (Packed Bed Bioreactor) [23]. The aim of the present study was to evaluate the effect of an initial aeration rate of $2 \mathrm{~mL} \min ^{-1} \mathrm{~g}^{-1}$ on the sporulation of six Trichoderma strains and to evaluate the behavior of the lytic enzymes involved in the process at laboratory scale.

\section{Materials and Methods}

\section{Microorganisms and Culture Conditions}

The strains of T. longibranchiatum, T. harzianum, T. yunnanense, T. asperellum (T2-10 and T2-31), and Trichoderma $s p$. were proportioned by the Department of Agricultural Parasitology of UAAAN (Universidad Autónoma Agraria Antonio Narro, Coahuila, Mexico). The fungal strains were cultured and preserved in a cryogenic solution of glycerolmilk $8.5 \%$. The strains were activated in sterilized PDA and incubated during 5 days at $29{ }^{\circ} \mathrm{C}$ to preserve at $4{ }^{\circ} \mathrm{C}$.

\section{Solid-State Fermentation (SSF)}

The SSF was performed using the modified Raimbault columns (diameter of $2.5 \mathrm{~cm}$ and height of $20 \mathrm{~cm}$ ) coupled to an air humidifier (Fig. 1). The aeration was generated by an air compressor and humidified by passing the air through distilled water. A flowmeter was used to adjust the initial aeration rate at $50 \mathrm{~mL} \mathrm{~min}^{-1}\left(2 \mathrm{~mL} \mathrm{~min}^{-1} \mathrm{~g}^{-1}\right)$ [22]. The columns were placed in a water bath to maintain the temperature at $29^{\circ} \mathrm{C}$. The substrate was integrated by a mix of sugarcane bagasse (40\%) as support, wheat bran (30\%), chitin (10\%), potato flour (10\%), and olive oil (10\%) on dry weight basis. Mixed substrates were sterilized at $121{ }^{\circ} \mathrm{C}$ for $30 \mathrm{~min}$. After cooling the substrate was inoculated with $2 \times 10^{7}$ spores $\mathrm{g}^{-1}$ dry matter. Initial $\mathrm{pH}$ was adjusted to 5.6 using $1.0 \mathrm{M} \mathrm{HCl}$ [24]. Each column was packed with 20 g solids at $75 \%$ of moisture (w/v) [25]. Each treatment was done in triplicates and monitored kinetically.
Fig. 1 Schematic representation of the SSF system. a compressor, $\mathbf{b}$ sterile filter $(0.22 \mu \mathrm{m}), \mathbf{c}$ water bath incubator, $\mathbf{d}$ packed bed column, $\mathbf{e}$ air humidifier, $\mathbf{f}$ fermented matter and $\mathbf{g}$ distilled water

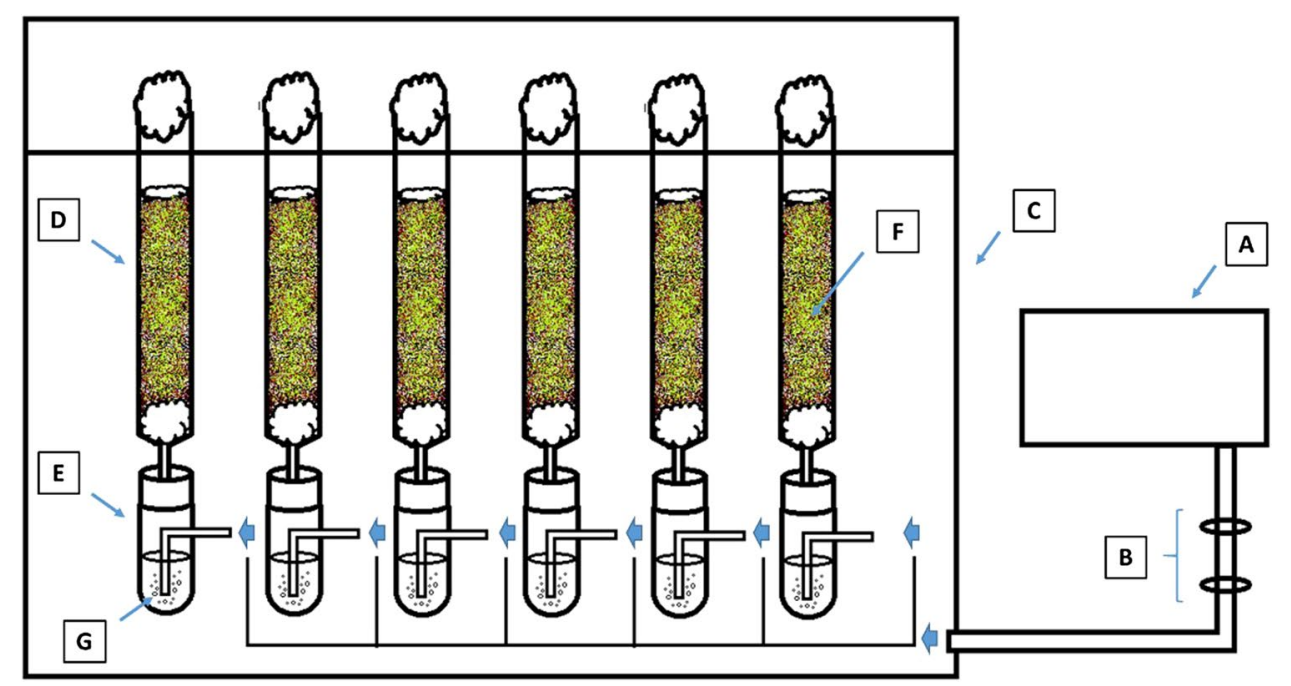




\section{Spore Determination}

The fermented matter $(1 \mathrm{~g})$ was added into $100 \mathrm{~mL}$ of Tween $80(0.01 \%)$ in an Erlenmeyer flask. A magnetic stirrer $(200 \mathrm{rpm})$ was used to release the spores from the solid matter and also to homogenize the suspension. The spores were counted using an hemocytometer.

\section{Enzyme Assays}

Fermented material $(5 \mathrm{~g})$ was mixed with $50 \mathrm{~mL}$ of distilled water, the suspension was homogenized using an Ultra-turax for $1 \mathrm{~min}$. Chitinase activity was determined using colloidal chitin $(1 \%)$ in citrate-phosphate $(50 \mathrm{mM}, \mathrm{pH} 5.0)$ at $50{ }^{\circ} \mathrm{C}$ for $30 \mathrm{~min}$. The reaction was cooled into an ice bath and after centrifuged at $10,000 \mathrm{~g}$ for $5 \mathrm{~min}$. Amylase activity was measured using soluble starch $(0.7 \%)$ in sodium citrate buffer $(50 \mathrm{mM}, \mathrm{pH} 5.9)$ at $50{ }^{\circ} \mathrm{C}$ for $15 \mathrm{~min}$. Endoglucanase activity was determined using carboxymethyl cellulose $(1 \%)$ in sodium citrate buffer $(50 \mathrm{mM}, \mathrm{pH} 4.8)$ at $50{ }^{\circ} \mathrm{C}$ for $30 \mathrm{~min}$, in according with Nava-Cruz et al. [26]. Exoglucanase activity was determined using filter paper Whatman No. $1(1 \mathrm{~cm} \times 5 \mathrm{~cm})$ in sodium citrate buffer $(50 \mathrm{mM}, \mathrm{pH}$ 4.8 ) at $50{ }^{\circ} \mathrm{C}$ for $60 \mathrm{~min}$ in according with Nava-Cruz et al. [26]. The four enzyme determinations mentioned above were stopped on a bath with ice for $5 \mathrm{~min}$. Sugars concentration was determined after each enzyme reaction according to the amount of resulting reducing sugars using 3,5-dinitro salicylic acid (DNS) following the assay method described by Miller [27]. An enzyme activity (U) was defined as the amount of enzyme that catalyzes the release of $1 \mu \mathrm{mol}$ of glucose per minute. Lipase activity was determined using $0.5 \mathrm{~mL}$ of $p$-nitrophenyl $(25 \mathrm{mM})$ in phosphate buffer $(25 \mathrm{mM}, \mathrm{pH} 7.0)$ at $30^{\circ} \mathrm{C}$ for $30 \mathrm{~min}$. The calibration curve was done with $p$-nitrophenol (0-100 ppm) and $412 \mathrm{~nm}$ was the wavelength used. An enzyme activity (U) was defined as the amount of enzyme required to release $1 \mu$ mole of $p$-nitrophenol per minute.

\section{Analysis and Experimental Design}

The experimental design was integrated by the evaluation six Trichoderma strains under two different culture conditions (aerated and not aerated). Each treatment was done in triplicate. The analysis of variance and means comparison (Tukey) were done in all cases. Data were analyzed by using the computer software, Statistical Package for Social Sciences (SPSS) version 23.0 for Windows and Microsoft Excel 2016.

\section{Results}

\section{Determination of the Enzyme Activities During the Solid-State Fermentation Without Aeration}

The highest value of chitinase activity was showed by $T$. harzianum ( $24.15 \mathrm{U} \mathrm{g}^{-1}$ at $72 \mathrm{~h}$ ), followed by T. yunnanense and T. asperellum T2-10 with 16.01 and $15.86 \mathrm{U} \mathrm{g}^{-1}$, respectively (Fig. 2b). T. harzianum also resulted in a great amylase activity ( $24.85 \mathrm{U} \mathrm{g}^{-1}$ at $72 \mathrm{~h}$ ) followed by Trichoderma spp. and T. yunnanense with 20.97 and $17.95 \mathrm{U} \mathrm{g}^{-1}$ at $72 \mathrm{~h}$, respectively (Fig. 2b). T. yunnanense and T. asperellum T2-10 showed the best endoglucanase activity (30.89 and $27.86 \mathrm{U} \mathrm{g}^{-1}$ at $72 \mathrm{~h}$, respectively), followed by T. harzianum with $22.03 \mathrm{U} \mathrm{g}^{-1}$ (Fig. 2c). The maximum exoglucanase activity was showed by $T$. longibranchiatum with a value of $9.29 \mathrm{U} \mathrm{g}^{-1}$ at $48 \mathrm{~h}$ (Fig. 2a). The rest of the strains showed values between 6.67 and $7.89 \mathrm{U} \mathrm{g}^{-1}$ at $72 \mathrm{~h}$. High lipase activities were showed by Trichoderma spp., and T. longibranchiatum (11.56 and $11.42 \mathrm{U} \mathrm{g}^{-1}$ at $72 \mathrm{~h}$, respectively) (Fig. 2e).

\section{Determination of the Enzyme Activities During the Aerated Solid-State Fermentation}

The great value for chitinase activity were showed by $T$. longibranchiatum ( $30.74 \mathrm{U} \mathrm{g}^{-1}$ at $48 \mathrm{~h}$ ), followed by $T$. harzianum and T. yunnanense with $21.42 \mathrm{U} \mathrm{g}^{-1}$ and $21.33 \mathrm{U} \mathrm{g}^{-1}$, respectively (Fig. 3a). These three strains also showed the best results for amylase activity. $T$ longibranchiatum started with an activity of $28.33 \mathrm{U} \mathrm{g}^{-1}$ at $24 \mathrm{~h}$, but reaching $44.54 \mathrm{U} \mathrm{g}^{-1}$ at $48 \mathrm{~h}$ (Fig. 3a). T. yunnanense and T. harzianum showed values of 33.68 and $21.57 \mathrm{U} \mathrm{g}^{-1}$, respectively at $72 \mathrm{~h}$. T. yunnanense showed an initial endoglucanase activity of $19.31 \mathrm{U} \mathrm{g}^{-1}$ at $24 \mathrm{~h}, 33.83 \mathrm{U} \mathrm{g}^{-1}$ at $48 \mathrm{~h}$ and reaching its maximum of $38.32 \mathrm{U} \mathrm{g}^{-1}$ at $72 \mathrm{~h}$ (Fig. 3c). High values of endoglucanase were also shown by $T$. harzianum $\left(31.70 \mathrm{U} \mathrm{g}^{-1}\right.$ at $\left.72 \mathrm{~h}\right)$ and $T$. longibranchiatum $\left(22.19 \mathrm{U} \mathrm{g}^{-1}\right.$ at $48 \mathrm{~h}$ ). The values of exoglucanase activity were homogeneous among all strains evaluated. The best enzyme value $\left(4.80 \mathrm{U} \mathrm{g}^{-1}\right)$ was showed by Trichoderma spp. at $72 \mathrm{~h}$ (Fig. 3e). However, high values of exoglucanase were also shown by $T$. yunnanense ( $3.66 \mathrm{U} \mathrm{g}^{-1}$ at $48 \mathrm{~h}$ ) and T. asperellum $\mathrm{T} 2-10$ (3.14 $\mathrm{U} \mathrm{g}^{-1}$ at $24 \mathrm{~h}$ ). T. longibranchiatum showed a lipase activity of $4.97 \mathrm{U} \mathrm{g}^{-1}$ at $24 \mathrm{~h}, 7.41 \mathrm{U} \mathrm{g}^{-1}$ at $48 \mathrm{~h}$ and reaching its maximum of $9.12 \mathrm{U} \mathrm{g}^{-1}$ at $72 \mathrm{~h}$ (Fig. 3a). Trichoderma spp. showed an activity of $6.77 \mathrm{U} \mathrm{g}^{-1}$ at $72 \mathrm{~h}$, followed by $T$. asperellum $\mathrm{T} 2-10\left(5.26 \mathrm{U} \mathrm{g}^{-1}\right.$ at $\left.72 \mathrm{~h}\right)$ and $T$. harzianum (5.06 $\mathrm{U} \mathrm{g}^{-1}$ at $48 \mathrm{~h}$ ). 


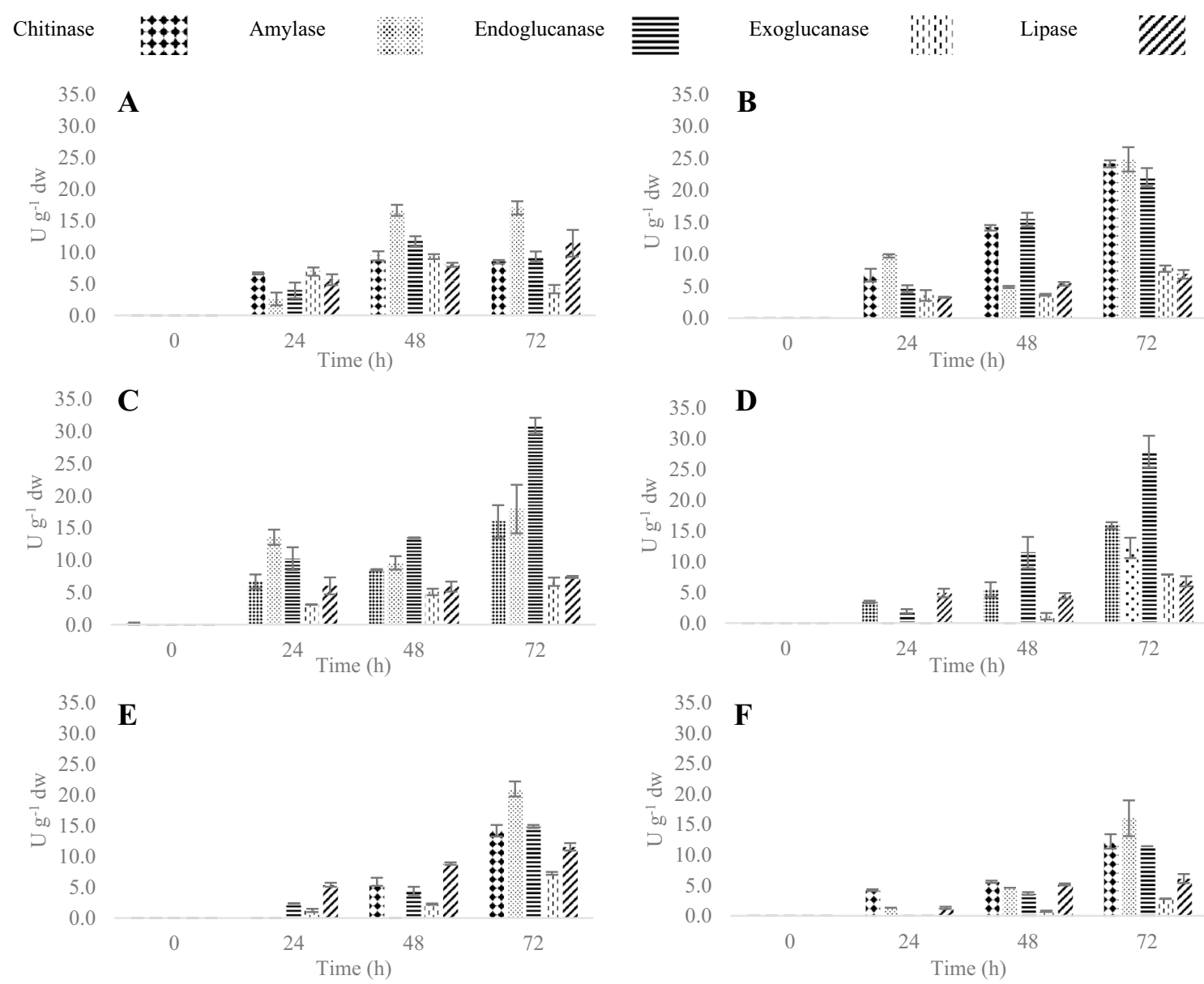

Fig. 2 Kinetic of lytic enzymes production under solid-state fermentation with passive aeration. a T. longibranchiatum, b T. harzianum, c T. yunnanense, $\mathbf{d}$ T. asperellum (T2-10), e Trichoderma spp., and $\mathbf{f}$ T. asperellum (T2-31)

\section{Effect of Forced Air Supply on Spore Production During the Solid-State Fermentation}

The maximum spore production for all six Trichoderma strains was achieved at $96 \mathrm{~h}$ of fermentation. T. longibranchiatum resulted in a production of $1.31 \times 10^{9}$ spores $\mathrm{g}^{-1} \mathrm{dw}$ (aerated) and $1.11 \times 10^{9}$ spores $\mathrm{g}^{-1}$ (not aerated). Since the $120 \mathrm{~h}$ of culture, the sporulation was maintained without important changes (Fig. 4a). T. harzianum showed faster lag phase when the system was aerated, reaching its higher value of $1.08 \times 10^{9}$ spores $\mathrm{g}^{-1} \mathrm{dw}$ at $96 \mathrm{~h}$. However, at the same time the system without aeration showed a value of $1.06 \times 10^{9}$ spores $\mathrm{g}^{-1} \mathrm{dw}$ (Fig. 4b). T. yunnanense and Trichoderma spp. showed a very similar pattern of spore production in the lag and exponential phase (Fig. 4c, e). T. yunnanense showed values of $1.20 \times 10^{9}$ spores $\mathrm{g}^{-1} \mathrm{dw}$ (aerated) and $1.08 \times 10^{9}$ spores $^{-1}$ (not aerated) as well as, Trichoderma spp. showed values of $1.10 \times 10^{9}$ spores $\mathrm{g}^{-1} \mathrm{dw}$ (aerated) and $1.18 \times 10^{9}$ spores $\mathrm{g}^{-1}$ (not aerated). The strains of T. asperellum (T2-10 and T2-31) resulted in a slow lag phase for the both systems, aerated and not aerated (Fig. 4d, f). Both strains showed its first values of spores until the $72 \mathrm{~h}$ of culture. After that, they reached the maximum spore production at $96 \mathrm{~h}$, like the others Trichoderma strains. $T$. asperellum $\mathrm{T} 2-10$ showed values of $1.23 \times 10^{9}$ spores $\mathrm{g}^{-1} \mathrm{dw}$ (aerated) and $1.11 \times 10^{9}$ spores $^{-1}$ (no aerated). In the case of T. asperellum T2-31, the values were $1.30 \times 10^{9}$ spores $\mathrm{g}^{-1} \mathrm{dw}$ (aerated) and $1.03 \times 10^{9}$ spores $\mathrm{g}^{-1}$ (not aerated).

\section{Discussion}

In this paper, the effect of forced air supply was evaluated on SSF for the production of spores and to determine the behavior of the lytic enzymes involved in the process at laboratory scale. Sugarcane bagasse was the major substrate used in the process to take advantage of its great characteristics to work as a source of nutrients and also as a matrix to anchor on it [12]. It is well known that sugarcane bagasse plays an important role because its high porosity allowing good water absorption, indispensable to carried out the microbial metabolism. Wheat bran, potato flour, chitin and olive 


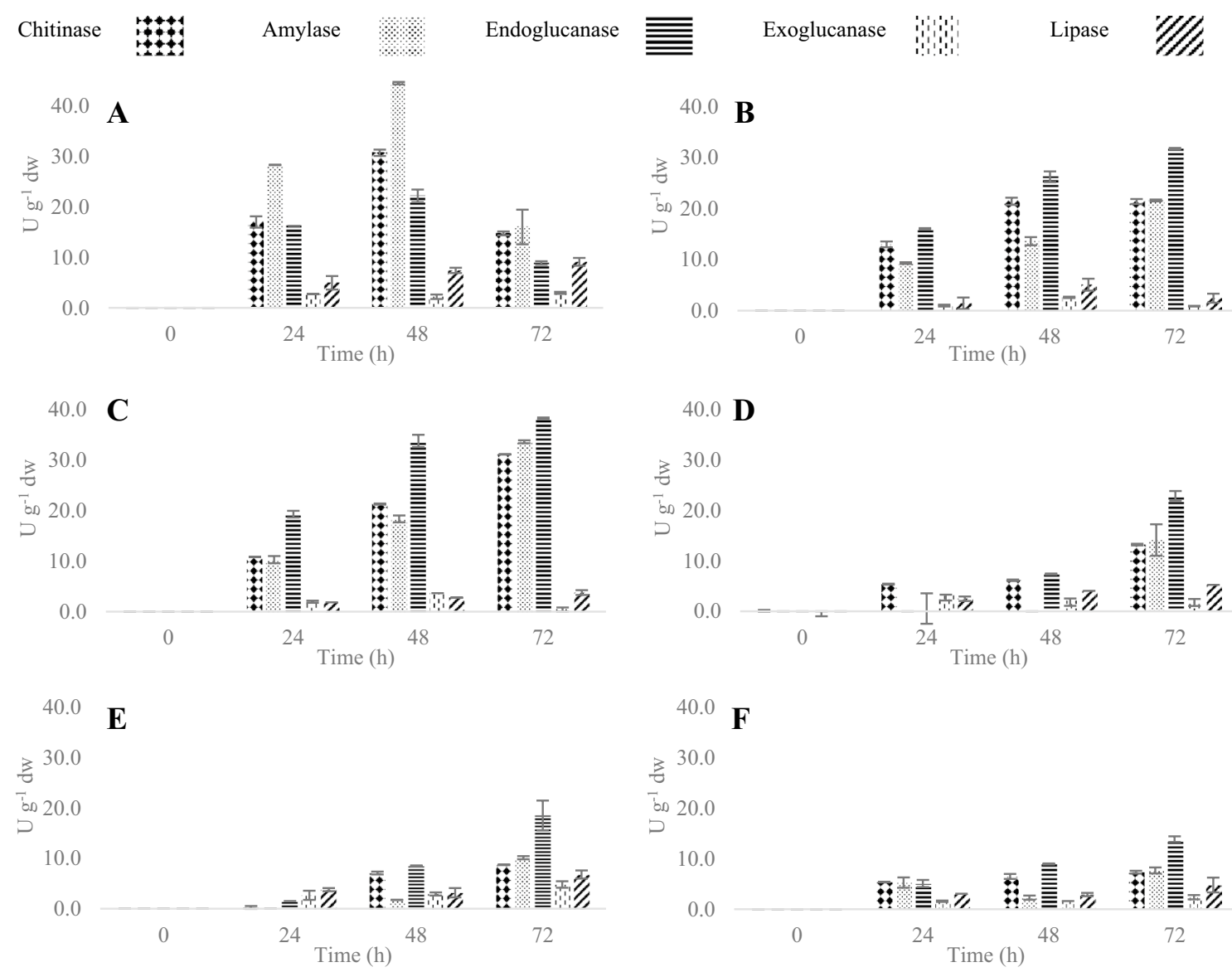

Fig. 3 Kinetic of lytic enzymes production under solid-state fermentation with forced aeration. a T. longibranchiatum, b T. harzianum, c T. yunnanense, $\mathbf{d}$ T. asperellum (T2-10), e Trichoderma spp., and $\mathbf{f}$ T. asperellum (T2-31)

oil were added as inducers of the lytic enzymes synthesis $[28,29]$. The strains $T$. longibranchiatum and T. yunnanense were benefited by the application of aeration on the SSF system for chitinase, amylase and endoglucanase activities. Despite this, the same conditions influenced a decrease on exoglucanase and lipase activities. This pattern was almost the same for T. harzianum, except for chitinase and amylase which were maintained without any effect of the air. $T$. asperellum $\mathrm{T} 2-10$ was affected negatively for endoglucanase and exoglucanase activities were reduced by the aeration, but the values of chitinase, amylase, and lipase were maintained with any modification by the application of air. The chitinase and amylase activities resulted diminished because of the aeration applied on T. asperellum T2-31. For this strain, the air represented an increment for endoglucanase, but it was not observed any change for exoglucanase and lipase. Trichoderma spp. was the most affected strain by the aeration. The values of chitinase, amylase, exoglucanase, and lipase were decreased by the application of air into the system. It is possible to observe homogenous patterns for exoglucanase and lipase activities, but in most of the cases, these two enzymes showed better activity under SSF with no aeration. Endoglucanase activity was higher when the air was applied which corresponds with the report of Kalogeris et al. [30]. The most significant differences between the values of enzymatic activity are shown in Table 1 . The application of air into a fermentation system could provide homogeneous environmental conditions, including the regulation of temperature and moisture which allows an enhancing in the carry of nutrients, metabolites and the oxygen diffusion through the solid substrate [23, 31]. However, the dehydration on the SSF is one of the main possible detrimental result caused by aeration and therefore is an important challenge for the production of enzymes [23, 29]. The values of the enzymes were highly variables suggesting that the enzyme activities were more related to the intrinsic capabilities of the present fungal strains than the effect of the air. Oliveira et al. [29], reported an improvement in lipase activity applying an aeration rate of $2 \mathrm{~mL} \mathrm{~min}^{-1} \mathrm{~g}^{-1} \mathrm{using}$ on an SSF with Aspergillus ibericus and wheat bran with $10 \%$ of olive oil as substrate. No fungal growth was observed when they tested the SSF without aeration. Despite this, an aeration rate above $8 \mathrm{~mL} \mathrm{~min}^{-1} \mathrm{~g}^{-1}$ also has a negative effect on lipase activity. A similar bioreactor was evaluated 

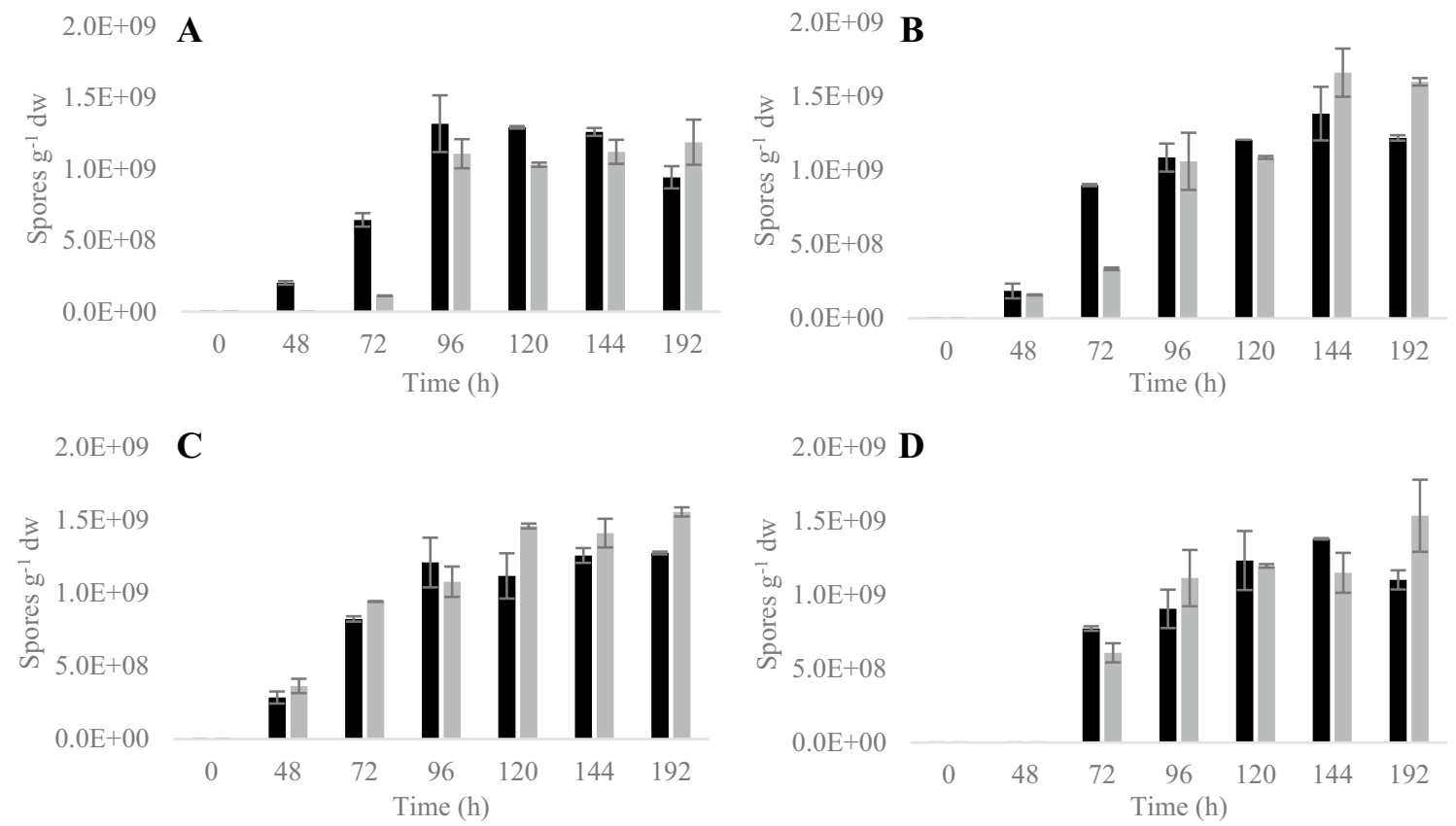

C

$2.0 \mathrm{E}+09 \mathbf{D}$
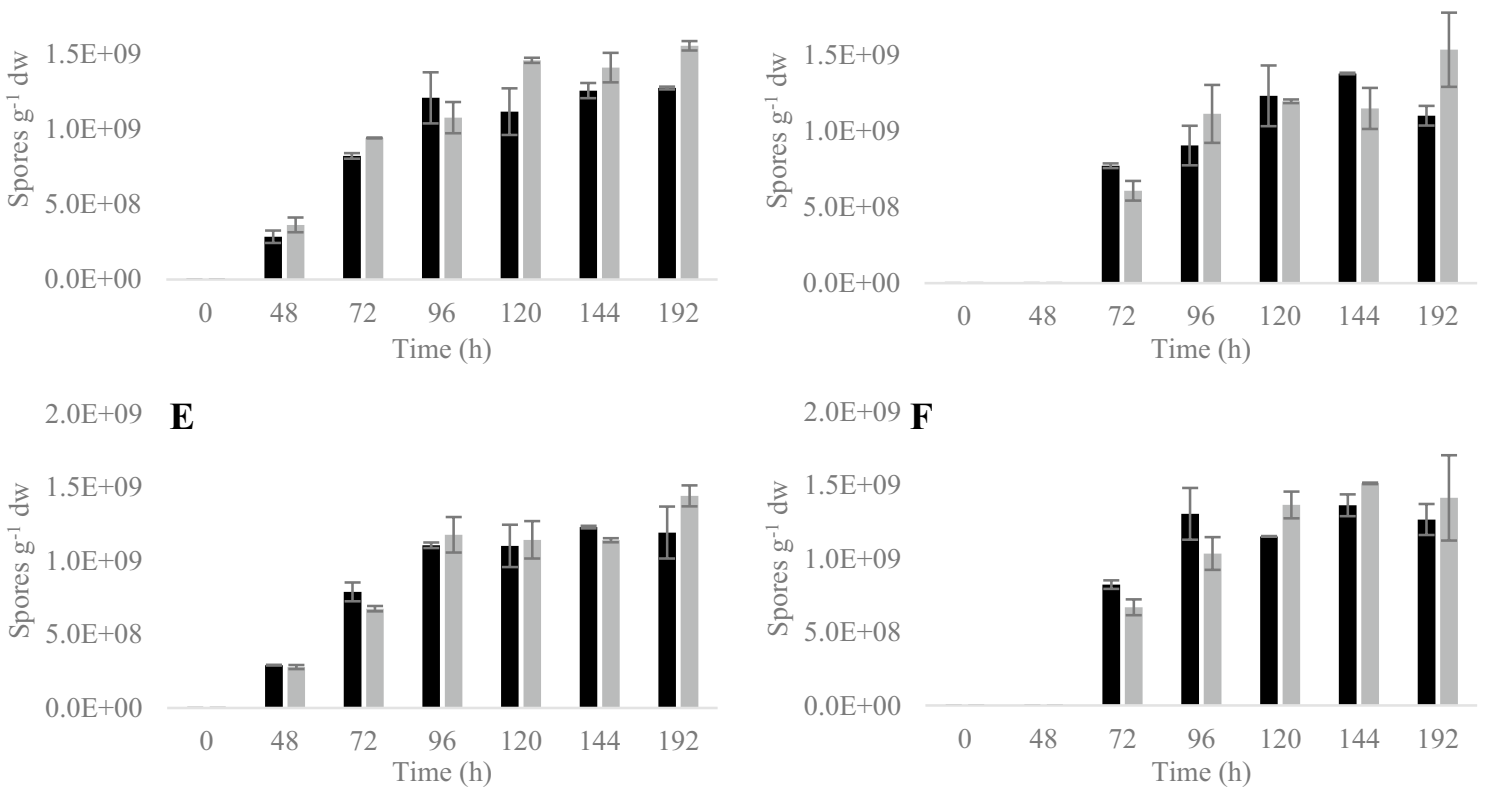

Fig. 4 Spore production under solid-state fermentation with aeration (black shaded bar) and without aeration (grey shaded bar). a T. longibranchiatum, b T. harzianum, c T. yunnanense, d T. asperellum (T2-10), e Trichoderma spp., and f T. asperellum (T2-31)

Table 1 The most significant values of the enzyme activities by Trichoderma strains

\begin{tabular}{lllll}
\hline Enzyme activity & Fungal strain & Fermentation system & $\begin{array}{l}\text { Culture time } \\
(\mathrm{h})\end{array}$ & $\begin{array}{l}\text { Enzyme } \\
\text { activity } \\
\left(\mathrm{U} \mathrm{g} \mathrm{g}^{-1}\right)\end{array}$ \\
\hline Chitinase & T. longibranchiatum & Aerated & 48 & $30.74^{\mathrm{a}}$ \\
& T. harzianum & Not aerated & 72 & $24.15^{\mathrm{b}}$ \\
Amylase & T. longibranchiatum & Aerated & 48 & $28.33^{\mathrm{a}}$ \\
& $T$. yunnanense & Aerated & 72 & $33.68^{\mathrm{b}}$ \\
Endoglucanase & T. yunnanense & Aerated & 72 & $38.32^{\mathrm{a}}$ \\
& T. yunnanense & Aerated & 72 & $31.70^{\mathrm{b}}$ \\
Exoglucanase & T. harzianum & Not aerated & 72 & $30.89^{\mathrm{b}}$ \\
Lipase & T. longibranchiatum & Not aerated & 48 & $9.29^{\mathrm{a}}$ \\
& T. longibranchiatum & Not aerated & 72 & $11.56^{\mathrm{a}}$ \\
& Trichoderma spp. & Not aerated & 72 & $11.42^{\mathrm{a}}$ \\
\hline
\end{tabular}

Means with different letter are significantly different according to the Tukey’s multiple range test $(\mathrm{p}<0.05)$ 
by Abdeshahian et al. [32] to enhance the cellulase activity from Aspergillus niger FTCC 5003. They used palm kernel cake as a substrate, reporting high activity when was applied an aeration rate of $15 \mathrm{~mL} \mathrm{~min}^{-1} \mathrm{~g}^{-1}$, but lower values at 5 and $10 \mathrm{~mL} \mathrm{~min}^{-1} \mathrm{~g}^{-1}$. This same values of aeration $(5,10$ and $15 \mathrm{~mL} \mathrm{~min}{ }^{-1} \mathrm{~g}^{-1}$ ) were evaluated by Kalogeris et al. [30] in an SSF process using wheat bran as substrate. They reported an improvement in the enzyme activities for endoglucanase, cellobiohydrolase, exoglucanase, xylanase, $\beta$-xylosidase and $\beta$-glucosidase from Thermoascus aurantiacus.

According to Motta and Santana [20], forced aeration has a high influence on the stimulation of fungal sporulation. They tested empty fruit bunches as substrate and a Trichoderma reesei strain evaluating an aeration rate of $16.6 \mathrm{~mL} \mathrm{~min}^{-1} \mathrm{~g}^{-1}$ resulting in $4.41 \times 10^{9}$ spores $\mathrm{g}^{-1}$ at $120 \mathrm{~h}$ of culture. However, they did not show data to support or compare that affirmation. Flodman and Noureddini [33] reported $7.50 \times 10^{8}$ spore $^{-1}$ of T. reseei using corncob wastes as a substrate on an Erlenmeyer bioreactor without aeration. Although the authors presented good results under their test, those values were 23 times less than the present work. The production of spores from Trichoderma asperellum T2-10 was evaluated in a previous work without application of aeration on the SSF [9]. The sporulation index was $1.4 \times 10^{9}$ spores $\mathrm{g}^{-1}$ using corn cob as substrate and a plastic bag as a bioreactor. In the present study, the forced aeration did not show any increase in the spore production for any of the six strains evaluated. This behavior suggests that the production of spores from the genus Trichoderma is not related with the air applied because of a possible minimal demand of oxygen, therefore the sporulation may not be oxygen-limited [22]. This outcome has a direct impact on the technical feasibility for the spore production of Trichoderma because under these culture conditions it is possible to use reactors such as flasks, trays or bags, which represents an energy saving related with the air control and also the laborious handling on the preparation of the fermentation process.

\section{Conclusion}

The chitinase, amylase and endoglucanase activities from T. longibranchiatum and T. yunnanense were enhanced through the application of forced aeration. For most of the strains, the aeration increased the endoglucanase activity. All strains showed low values of exoglucanase and lipase when the aeration was applied. Trichoderma spp. was the strain most affected negatively by the aerated process, showing the lowest enzyme activities. The results obtained suggest that chitinase and amylase could be more dependent on the Trichoderma strain than the aeration applied. The forced air supply into solid-state fermentation did not improve the production of spores from Trichoderma since similar production was obtained in the process without forced aeration. On this report, we reach concentrations greater than $1 \times 10^{9}$ spores per gram of substrate at $96-120 \mathrm{~h}$ of culture, indicating a feasible approach of agro-industrial wastes as a substrate for the biomass production.

Acknowledgements Authors thank National Council of Science and Technology of Mexico (CONACYT) for the financial support during the stay in France (Scholarship No. 373326). The authors also thank Department of Food Research (Mexico), Institut de Recherché pour le Development (IRD), the Institut Méditerranén de Biodiversité et d'Ecologie Marine et Continentale (IMBE), and the planning direction office of the Universidad Autónoma de Coahuila (UAdeC) for the support and technical facilities.

\section{Compliance with Ethical Standards}

Conflict of interest The authors declare that they have no conflict of interest.

\section{References}

1. Sain, S.K., Pandey, A.K.: Biological spectrum of Trichoderma harzianum Rifai isolates to control fungal diseases of tomato (Solanum lycopersicon L.). Arch. Phytopathol. Plant Protect. 49, 19-20 (2016)

2. Innocenti, G., Roberti, R., Piattoni, F.: Biocontrol ability of Trichoderma harzianum strain T22 against Fusarium wilt disease on water-stressed lettuce plants. Biocontrol 60(4), 573-581 (2015)

3. Miranda-Hernández, F., Garza-López, P.M., Loera, O.: Cellular signaling in cross protection: An alternative to improve mycopesticides. Biol. Control. 103, 196-203 (2016)

4. Jackson, M.A., Dunlap, C.A., Jaronski, S.T.: Ecological considerations in producing and formulating fungal entomopathogens for use in insect biocontrol. In: The ecology of fungal entomopathogens. pp. 129-145. Springer, Dordrecht (2010)

5. Technavio: Global agricutural biologicals market 2016-2021, p. 70. Infiniti Research Limited, Toronto (2017)

6. Loera-Corral, O., Porcayo-Loza, J., Montesinos-Matias, R., Favela-Torres, E.: Production of conidia by the fungus Metarhizium anisopliae using solid-state fermentation. Microbial-based biopesticides: methods and protocols, In: Glare, T.R., MoranDiez, M.E. (eds.). pp. 61-69. Springer, New York (2016)

7. Shah, P., Pell, J.K.: Entomopathogenic fungi as biological control agents. Appl. Microbiol. Biotechnol. 61, 413-423 (2012)

8. Lopez-Perez, M., Rodriguez-Gomez, D., Loera, O.: Production of conidia of Beauveria bassiana in solid-state culture: current status and future perspectives. Crit. Rev. Biotechnol. 35(3), 334-341 (2015)

9. de la Cruz-Quiroz, R., Roussos, S., Hernandez-Castillo, D., Rodríguez-Herrera, R., López, L.I.L., Castillo, F., Aguilar, C.N.: Solid-State Fermentation in a Bag Bioreactor: Effect of Corn Cob Mixed with Phytopathogen Biomass on Spore and Cellulase Production by Trichoderma asperellum. In: Fermentation Processes, A.F., Jozala, Editor. pp. Ch. 03. InTech (2017)

10. Velasco-Lozano, S., Volke-Sepulveda, T., Favela-Torres, E.: Lipases Production by Solid-State Fermentation: The Case of Rhizopus homothallicus in Perlite. In: Sandoval, G. Lipases and phospholipases: methods and protocols, pp. 227-237. Humana Press, New York (2012)

11. Viniegra-González, G.: New Horizons for the Production of Industrial Enzymes by Solid-State Fermentation. In: Biosystems 
Engineering: Biofactories for Food Production in the Century XXI, Guevara-Gonzalez, R., Torres-Pacheco, I. (eds.). pp. 319340. Springer International Publishing, New York (2014)

12. Sarhy-Bagnon, V., Lozano, P., Saucedo-Castañeda, G., Roussos, S.: Production of 6-pentyl- $\alpha$-pyrone by Trichoderma harzianum in liquid and solid state cultures. Process Biochem. 36(1-2), 103109 (2000)

13. Chen, L., Yang, X., Raza, W., Luo, J., Zhang, F., Shen, Q.: Solidstate fermentation of agro-industrial wastes to produce bioorganic fertilizer for the biocontrol of Fusarium wilt of cucumber in continuously cropped soil. Bioresour. Technol. 102(4), 3900-3910 (2011)

14. Mascarin, G.M., Jaronski, S.T.: The production and uses of Beauveria bassiana as a microbial insecticide. World J. Microbiol. Biotechnol. 32(11), 177 (2016)

15. Thomas, L., Larroche, C., Pandey, A.: Current developments in solid-state fermentation. Biochem. Eng. J. 81, 146-161 (2013)

16. Mishra, S., Kumar, P., Malik, A.: Suitability of agricultural byproducts as production medium for spore production by Beauveria bassiana HQ917687. Int. J. Recycl. Org. Waste Agric. 5(2), 179-184 (2016)

17. Abraham, T., Easwaramoorthy, S., Santhalakshmi, G.: Mass production ofbeauveria bassiana isolated from sugarcane root borer,emmalocera depresella swinhoe. Sugar Tech. 5(4), 225-229 (2003)

18. Raghuwanshi, S., Deswal, D., Karp, M., Kuhad, R.C.: Bioprocessing of enhanced cellulase production from a mutant of Trichoderma asperellum RCK2011 and its application in hydrolysis of cellulose. Fuel 124, 183-189 (2014)

19. Sindhu, R., Gnansounou, E., Binod, P., Pandey, A.: Bioconversion of sugarcane crop residue for value added products-an overview. Renew. Energy 98, 203-215 (2016)

20. Motta, F.L., Santana, M.H.A.: Solid-state fermentation for humic acids production by a Trichoderma reesei strain using an oil palm empty fruit bunch as the substrate. Appl. Biochem. Biotechnol. 172(4), 2205-2217 (2014)

21. Muñiz-Paredes, F., Garza-López, P.M., Viniegra-González, G., Loera, O.: Comparison between superficial and solid-state cultures of Isaria fumosorosea: conidial yields, quality and sensitivity to oxidant conditions. World J. Microbiol. Biotechnol. 32(7), 111 (2016)

22. Arzumanov, T., Jenkins, N., Roussos, S.: Effect of aeration and substrate moisture content on sporulation of Metarhizium anisopliae var. acridum. Process Biochem. 40(3-4), 1037-1042 (2005)
23. Melikoglu, M., Lin, C.S.K., Webb, C.: Solid state fermentation of waste bread pieces by Aspergillus awamori: analysing the effects of airflow rate on enzyme production in packed bed bioreactors. Food Bioprod. Process. 95, 63-75 (2015)

24. Roussos, S., Olmos, A., Raimbault, M., Saucedo-Castañeda, G., Lonsane, B.K.: Strategies for large scale inoculum development for solid state fermentation system: conidiospores of Trichoderma harzianum. Biotechnol. Tech. 5(6), 415-420 (1991)

25. Roussos, S., Raimbault, M., Saucedo-Castañeda, G., Lonsane, B.: Efficient leaching of cellulases produced byTrichoderma harzianum in solid state fermentation. Biotechnol. Tech. 6(5), 429-432 (1992)

26. Nava-Cruz, N.Y., Contreras-Esquivel, J.C., Aguilar-González, M.A., Nuncio, A., Rodríguez-Herrera, R., Aguilar, C.N.: Agave atrovirens fibers as substrate and support for solid-state fermentation for cellulase production by Trichoderma asperellum. 3 Biotech. 6(1), 115 (2016)

27. Miller, G.: Use of dinitrosalicylic acid reagent for determination of reducing sugar. Anal. Chem. 31(3), 426-428 (1959)

28. Shi, Y., Xu, X., Zhu, Y.: Optimization of Verticillium lecanii spore production in solid-state fermentation on sugarcane bagasse. Appl. Microbiol. Biotechnol. 82(5), 921 (2009)

29. Oliveira, F., Salgado, J.M., Abrunhosa, L., Pérez-Rodríguez, N., Domínguez, J.M., Venâncio, A., Belo, I.: Optimization of lipase production by solid-state fermentation of olive pomace: from flask to laboratory-scale packed-bed bioreactor. Bioprocess Biosyst. Eng. 40(7), 1123-1132 (2017)

30. Kalogeris, E., Iniotaki, F., Topakas, E., Christakopoulos, P., Kekos, D., Macris, B.J.: Performance of an intermittent agitation rotating drum type bioreactor for solid-state fermentation of wheat straw. Bioresour. Technol. 86(3), 207-213 (2003)

31. De los Santos-Villalobos, S., Hernández-Rodríguez, L.E., Villaseñor-Ortega, F., Peña-Cabriales, J.J.: Production of Trichoderma asperellum T8a spores by a "home-made" solid-state fermentation of mango industrial wastes. BioResources 7(4), 4938-4951 (2012)

32. Abdeshahian, P., Samat, N., Hamid, A.A., Yusoff, W.M.W.: Solid substrate fermentation for cellulase production using palm kernel cake as a renewable lignocellulosic source in packed-bed bioreactor. Biotechnol. Bioprocess Eng. 16(2), 238-244 (2011)

33. Flodman, H.R., Noureddini, H.: Effects of intermittent mechanical mixing on solid-state fermentation of wet corn distillers grain with Trichoderma reesei. Biochem. Eng. J. 81, 24-28 (2013) 